\title{
Effect of glucagon on learning an avoidance-escape response in the albino rat
}

\author{
H. A. TILSON AND D. C. COGAN, DEPARTMENT OF PSY- \\ CHOLOGY, TEXAS TECHNOLOGICAL COLLEGE, Lubbock, \\ Tex. 79409
}

Eight albino rats were randomly divided into two groups, nondrugged (Group $N$ ) and drugged (Group D), and were trained on an avoidance-escape task in a modified Warner shuttle box. Ss in Group $D$ received $.2 \mathrm{cc}$ of glucagon 15 min before each test session; Ss in Group $N$ received 2 cc of normal saline solution 15 min before each session. Mean trials to criterion of learning, and mean latency of response compared by $t$ tests indicated reliable differences between groups $(p<.05)$. The reliable differences were attributed to the action of the glucagon.

A review of the literature concerning hormonal influence on learning indicates that there is little or no effect on learning ability in the adult $S$ due to changes in hormonal levels or the removal of a gland in adulthood, that there are no observable changes in maze-learning ability following castration or hypophysectomy in adult animals, and that learning ability has seldom been altered by thyroidectomy or the administration of thyroid hormone in adulthood (Morgan, 1965).

By contrast, a thyroid inhibitor, allyl thiourea, has been reported as having an impairing effect on maze-learning (Scow, 1946). Moderate doses of adrenal cortical hormones have been shown to increase the maze-learning ability of food-deprived rats (Reiss, 1947), and insulin was found to have an impairing effect on maze-learning in the rat (Reiss \& Berman, 1942). No effect was observed on avoidance-learning when the adrenal medulla of rats was removed (Moyer \& Bunnell, 1958).

The studies of Reiss (1947) and Reiss \& Berman (1942) demonstrated that learning ability was affected negatively and positively, respectively, by the related hormones of insulin and adrenal cortical steroids. Ingle (1941) demonstrated that some steroid extracts of the adrenal cortex are physiologically considered as insulin antagonists or at least to have an opposite effect on the blood glucose and glycogen disposition than insulin. Similarly, the hyperglycemic glycogenolytic factor (HGF), a protein believed to be secreted by the alpha cells of the pancreas (Hoerr \& Osol, 1956), is reported to have an effect opposite to that of insulin (Morgan, 1965, p. 97). The action of HGF (glucagon), specifically, is on the glycogen in the liver cells, breaking glycogen down to glucose which enters the blood stream (Lee \& Knowles, 1965). Because the physiological effect of HGF is similar in its effect to the adrenal cortical steroids by its action on the liver and is dissimilar in its physiological effect to that of insulin, HGF should also have a positive effect on learning. The purpose of the study was to determine the nature of the effect of HGF on learning ability in adult albino rats.

Subjects. The Ss were eight albino rats, four males and four females, approximately 110-120 days old at the beginning of the experiment and were of the Holtzman-Shaw strain maintained at Texas Technological College. Ss were maintained throughout on ad lib food and water.

Apparatus. The Ss were run in a modified Warner shuttle box (Warner, 1932). The test equipment consisted of a plywood box $9 \mathrm{in}$. long, 8 in. wide, and $10 \%$ in. in height, painted flat black. The floor consisted of a grid of 24 parallel metallic bars, separated by $1 / 2$ in. and having a diameter of about $1 / 16$ in. The ceiling and wall facing the $\mathrm{E}$ was made of Plexiglas, enabling clear observation from a distance of at least $6 \mathrm{ft}$. A fence, $7 / 8$ in. in height and made of wood with two electrodes directly above and parallel to it, divided the apparatus into two equal halves. The sound source consisted of a $115 \mathrm{~V}$ relay built into the back of the box, operated manually by a microswitch.

Shock was administered manually by a toggle switch which delivered $115 \mathrm{~V}$ onto the grids after stepping down line current to a maximum of $1 \mathrm{~mA}$. Time intervals were measured by an assistant operating a Cletimer stop watch.

Procedure. The Ss were divided into groups of male and female and randomly assigned to Group D (glucagon) or Group N (control) with an equal number of each sex in each group. Ss were assigned a number from the table of random numbers, and a sequence chart was devised to arrange random order of the running of the trials. In all cases, this arrangement was used for all phases except the posttesting phase. The learning situation was divided into three phases, training, testing, and posttesting.

Training phase. The Ss were placed into the apparatus for a 5 min interval without any stimulation other than that of the surroundings of the box. Five $1 \mathrm{sec}$ soundings of the buzzer, separated by intervals of $15 \mathrm{sec}$, were then given. One sec after the fifth sound stimulus, a mild electric shock was administered and was continued until the $S$ somehow crossed the fence. The whole sequence of events was repeated after a period of $30 \mathrm{sec}$. A total of 20 trials per day for three consecutive days were given. No injections were given during this phase.

Test phase. The day following the preliminary 60 trials, the Ss began the test phase. Deviations from Warner's procedure (1932) during this phase were due to the relatively fast action of the HGF, which has its maximum effect on blood sugar level in a period of about $20 \mathrm{~min}$ following injection (Lukens, 1959).

Injections were given $15 \mathrm{~min}$ before each test session was to begin. Group $D$ received I.M. injections of .2 cc of HGF solution prepared from $1 \mathrm{mg} / 1000$ $\mathrm{ml}$ of distilled water, which was enough to obtain a minimum rise of blood sugar level of approximately $300 \mathrm{mg} / \mathrm{ml}$ of blood (Turner, 1966). Group N received $2 \mathrm{cc}$ of normal saline solution.

The Ss were placed in the shuttle box for 5 min preceding the onset of the first trial. Each trial consisted of the presentation of a sound stimuls for $1 \mathrm{sec}$, followed by an interval of $1 \mathrm{sec}$, then the administration of shock until a response of jumping or crossing over the fence was made. This was followed by a $10 \mathrm{sec}$ interval and the beginning of the cycle again. If the $\mathrm{S}$ crossed before the $1 \mathrm{sec}$ interval was completed (CR), no shock was given. The criterion of learning as established by Warner (1932) was defined as five consecutive CRs. Length of test session was determined by a period of $10 \mathrm{~min}$ or 50 trials, whichever came first.

Posttest phase. Immediately following the day after the criterion of learning had been reached, the Ss were given 10 more trials exactly like those of the test phase with the exception that there was no buzzer, no shock, and no injection. There was the same presession period of $5 \mathrm{~min}$, clicks of the switches when the stimulus and shock were to be given, and the correct time intervals observed. The posttest phase was executed to determine if the Ss were learning cues not intended as part of the learning situation.

Results. A $t$ test for the difference between means of trials to criterion was reliable $(t=2.13$, $\mathrm{df}=6, \mathrm{p}<.05)$. Group $\mathrm{D}$ averaged 185.8 trials to reach the criterion of learning and Group $\mathrm{N}$ averaged 309.0 trials. Group D averaged $1.67 \mathrm{sec}$ to cross, leap, jump or hurdle the fence after the administration of shock, while Group $\mathrm{N}$ averaged $2.16 \mathrm{sec}$ for the same response. A t test for the difference between mean latencies of the response was reliable $(t=$ $2.04, \mathrm{df}=6, \mathrm{p}<.05$ ). A comparison of data collected for the posttest phase revealed that there were two apparent CRs made at the proper times, but these responses were divided equally between the groups.

Conclusion. The reliable mean differences of trials to criterion and latency of response tend to support the hypothesis that there was a positive effect on learning for Group D. The findings of Reiss (1947) were generally supported. The reliable differences can, probably, be attributed to the action of the HGF. The increased blood sugar level as a result of the release of glucose from glycogen due to the action of the HGF on the liver appears to have been the salient factor in the effect on learning for Group D.

In the interpretation of the data as indicating a positive effect on learning by the action of the HGF, the possibility of general activity as the critical variable could be raised. There were, however, no observable or obvious differences in general activity as measured by number of defecations; washing activity in the shuttle box, carrying cage, and intertrial interval cage; superfluous leaping and jumping at the sound of buzzer and administration of shock; gnawing on the grids and shuttle box; and racing or roaming from one side of the box to the other between trials. On the basis of these observations, it seems unlikely that general activity was the major causative factor producing the observed differences. 
In general, these data tend to indicate that certain hormonal or biochemical processes have an effect on learning rate or level, or both. More specifically, an increase in blood sugar level improves learning while a decrease seems to interfere with learning.

\section{REFERENCES}

HOERR, N. L., \& OSOL, A. (Eds.) Blakiston's new Gould medical dictionary. (2nd ed.) New York: McGraw-Hill, 1956.

INGLE, D. J. Relation between insulin and the adrenal cortical hormones. Endocrinology, 1941, 29, 649-653.

LEE, J., \& KNOWLES, F. W. Animal hormones. London: Hutchinson, 1965. LUKENS, F. W. The pancreas: Insulin and glucagon. Annu. Rev. Physiol. $1959,21,445-475$.

MORGAN, C. T. Physiological psychology. (3rd. ed.) New York: McGrawHill, 1965.
MOYER, K. E., \& BUNNELL, B. N. Effect of injected adrenalin on an avoidance response in the rat. J. genet. Psychol., 1958, 92, 247-251.

MOYER, K. E., \& BUNNELL, B. N. Effect of adrenal demedullation on an avoidance response in the rat. J. comp. physiol. Psychol., 1959, 52, 215-216.

REISS, B. F. Some effects of adrenal cortical steriod hormones on the maze behavior of the rat. J. comp. physiol. Psychol., 1947, 40, 9-11.

REISS, B. F., \& BERMAN, L. Effect of insulin shock in learning in the white rat. Science, 1942, 95, 511-512.

SCOW, R. O. The retarding effect of allyl thiourea and of partial thyroidectomy at birth upon learning in the rat. J. comp. physiol. Psychol., 1946, 39, 359-370.

TURNER, C. O. General endocrinology. (4th ed.) Philadelphia: W. B. Saunders, 1966.

WARNER, L. H. The association span of the white rat. J. genet. Psyihol., $1932,41,57-89$. 